\title{
Bacterial abundance and potential grazing (top-down) influence on Specific Growth Rate of heterotrophic bacteria in the river Cauvery and its upstream tributaries in southern Karnataka.
}

\author{
M. Mahadevaswamy \\ Department of Zoology, Yuvaraja's College, University of Mysore \\ Mysuru-570005, Karnataka, India \\ Cell phone number: 9480166620 \\ *Corresponding Author Email: maadhuycm@gmail.com \\ DOI: $10.29322 /$ IJSRP.10.07.2020.p10361 \\ http://dx.doi.org/10.29322/IJSRP.10.07.2020.p10361
}

\begin{abstract}
The specific growth rate of heterotrophic bacteria is determined by dividing the production between the biomass, is an indicator of the capacity of the bacterial population to replace its biomass. The eukaryotic heterotrophic flagellates and ciliates are important grazers on bacteria, thus potentially influencing the abundance by selective feeding within the 'microbial loop'. Mid stream surface water samples from all the water courses selected were collected in a sterile glass bottles. Water samples were screened through Whatman GF/A (1.63 $\mu \mathrm{m}$ nominal pore size) glass micro fibre filters. The SGR was calculated by taking only the abundance of bacterioplankton at the beginning $(0 \mathrm{~h})$ and at the end $(48 \mathrm{~h})$ incubation period. Mean value of SGR of bacteria was similar in the rivers Harangi $\left(0.0024 \mathrm{~h}^{-1}\right)$, Hemavathy $\left(0.0031 \mathrm{~h}^{-1}\right)$, Lokapavani $\left(0.0030 \mathrm{~h}^{-1}\right)$ and Cauvery $\left(0.0033 \mathrm{~h}^{-1}\right)$. But it was more and significantly different in the river Lakshmanatheertha $\left(0.0042 \mathrm{~h}^{-1}\right)$. More negative variations of SGR of bacteria was noticed in the river Lakshmanatheertha (15); compared to rivers Harangi (2), Hemavathy (1), Lokapavani (3) and Cauvery (2). The negative growth rates were due to decrease in the observed bacterial cell counts after $48 \mathrm{~h}$ incubation. The calculations of Pearson's Correlation Coefficients after $\log _{10}$ transformation showed both negative and positive relations of bacterial abundance with the SGR. The negative correlation implies that, lesser the bacterial abundance higher will be the SGR of planktonic bacteria. Relatively low bacterial abundance could be ascribed to the differential interactions among bacterial growth rate, substrate supply, bacteriophages, bacterivory and other predation in regulating bacterial abundance.
\end{abstract}

Key words: Bacterial abundance, river Lokapavani, Bacterial growth, Heterotrophic flagellates, Negative correlations.

\section{INTRODUCTION}

Heterotrophic bacteria in the fresh water ecosystem form a major part of the food web and mediate important processes in the carbon budget (Findlay, et al., 1998; Kirchman, 2008). This food web plays a crucial role in the regulation of carbon transfer (Jugnia, et al., 2000; Kirchman, 2015), and as a consequence of the high growth potential of the heterotrophic bacterioplankton (Azam et al., 1983; Sanders et al 1992; Simek, et al., 2006). There are many studies which have suggested that heterotrophic bacteria can also utilize a large fraction of the carbon that flows within the ecosystems, and by virtue of their abundance, ability to use dilute substrate, high assimilation efficiencies and rapid growth rates represent a significant resources available to support the next higher trophic level in the aquatic ecosystem (Kritzberg, et al., 2004; Alonso-Sáez et al., 2008; Kirchman et al., 2009). The ecological importance of heterotrophic bacteria has led to much attention being paid to the abundance, biomass and activity of bacterioplankton. Over the last decade or so, there has been emphasis on obtaining estimates of bacterial growth and secondary production, in many trophodynamic studies of planktonic bacteria (Chrzanowski and Grover, 2001). Pace, et al., (1990) reported that on annual time scale, the abundance is remarkably stable, growth rates are sufficient to allow population turnover in much 
shorter time scales. The specific growth rate, determined by dividing the production between the biomass, is an indicator of the capacity of the bacterial population to replace its biomass (Iriberri et al., 1990; Lønborg et al., 2011). Much of the primary production in aquatic ecosystems is processed by planktonic bacteria (Giorgio and Cole, 1998). The heterotrophic bacteria serve as food for protozoan and metazoan (Hessen, 1998) and can ultimately support the growth of micro crustaceans (Travnik, 1998). The eukaryotic protozoa, especially the heterotrophic flagellates and ciliates, are important grazers on bacteria (Jürgens and Massana, 2008; Vaqué et al., 2014), thus potentially influencing the abundance by selective feeding within the 'microbial loop' inturn interfere with the growth of the bacterioplankton. More recently, several investigators have demonstrated that, bacterial growth in aquatic ecosystems can be limited by the predation (Caron, 1991; Huete-Stauffer et al., 2015), substrate supply (Rivkin and Anderson, 1997), allochthonous DOC (del Giorgio and peters, 1994; Church, 2008), and viral infections (Proctor and Fuhrman, 1992; Vaqué et al., 2014), rather than the supply of organic carbon (Pomeroy, et al., 1995; Carlsson and Caron, 2001). Furthermore, estimations of bacterial growth rate and production are essential for determining the role of bacteria in the trophic dynamics of ecosystems (Iriberri et al., 1990). New estimates of bacterial growth rates have been made over the past few years by a variety of techniques (Li, 1984), but the study of growth dynamics of natural bacterial assemblages in situ is still very much in its infancy. The most research on the population ecology of marine bacteria continues to be carried out in rich coastal and shelf waters. Much less has been done in open ocean regions and also in lotic ecosystem like streams and rivers (Sinsabaugh et al., 1997; Foreman, et al., 1998; Yamakanamardi and Goulder, 1999, Harsha et al, 2009). This author is aware of only a limited number of studies that have quantified the specific growth rate of bacterioplankton, Berman et al., (1994); Chrzanowski and Grover (2001); Carlsson and Caron (2001) and Šimek et al., (2006) have measured bacterial growth rate in response to substrate addition. So far there are no studies reported on the specific growth rate of planktonic heterotrophic bacteria in river Cauvery and its important tributaries like Lakshmanatheertha, Harangi, Hemavathy and Lokapavani in Karnataka state, India. Hence, this investigation on the specific growth rate of planktonic bacteria was under taken. The main aims of the study were: 1] To test the hypothesis that the mean specific growth rate of heterotrophic bacteria in all the four upstream tributaries is similar to each other, but markedly different in the main river Cauvery. 2] To investigate the relationships between specific growth rates $(k)$ of heterotrophic bacteria with other microbial variables in these five water courses. 3). To know, the potential control of mean specific growth rate of heterotrophic bacteria by top-down control or grazing.

\section{MATERIALS AND METHODS}

\section{Sample collection}

For the study of specific growth rate of planktonic bacteria, mid stream surface water samples from the river Lakshmanatheertha, Harangi, Hemavathy, Lokapavani and Cauvery were collected in a sterile glass bottles (Schott-Duran, Germany) and were transported back to the laboratory on ice. The water samples were screened through Whatman GF/A (1.63 $\mu \mathrm{m}$ nominal pore size) glass micro fibre filters to remove micro zooplanktons which act as grazers. This filtration process does not reduce bacterial numbers although phytoplankton was largely removed (Lambert, Taylor and Goulder, 1993, Yamakanamardi and Goulder, 1999, Harsha et al 2009). Approximately $505 \mathrm{ml}$ of pre filtered sample was transferred to 1 liter sterile glass conical flask (Borosil India Ltd, Mumbai). Two replicate flasks were used for each site. All the flasks were closed with aluminum foil. A $5 \mathrm{ml}$ aliquot was taken from each flask at zero time and fixed immediately with $0.2 \mu \mathrm{m}$ filtered neutral formalin (2\% final concentration). Then all the conical flasks were placed in an Environ-Orbit shaker (Lab-line Instrumentals, USA) running at river water temperature (water temperature which was mean of all the sampling sites) and 90 revolutions per minute.

\section{Evaluation of method}

On two occasions mid-stream surface water samples from all five sites were collected. Next, two $5 \mathrm{ml}$ of aliquots were collected at 12, 24, 36 and $48 \mathrm{~h}$ and were fixed immediately with $0.2 \mu \mathrm{m}$ filtered neutral formalin ( $2 \%$ final concentration) and 
were stained with Acridine orange stain. The bacterial abundance from these fixed samples was counted by using Epifluorescence microscopy. In this study, specific growth rate (as cells per cells per hour), was routinely calculated from direct counts of bacteria at beginning $(0 \mathrm{~h})$ and end of incubation for $48 \mathrm{~h}$ in GF/A filtered, unsupplimented natural water samples. Koch (1981) mentions use of the symbols K and $\mu$ for specific growth. Ducklow and Hill (1985); Fry (1990) however, preferred $\mu\left(\mathrm{h}^{-1}\right)$ for specific growth rate. In the present work $K\left(\mathrm{~h}^{-1}\right)$ is used to express the specific growth of bacterioplankton. The specific growth rate $\left(k \mathrm{~h}^{-1}\right)$ of bacterioplankton was determined using the following two approaches- (1) From linear regression of $\log _{\mathrm{e}}$ cell concentration against time. A graph was plotted using concentration of acridine orange counts of bacteria at 12, 24, 36 and 48 hours against time, with the help of sigma plot 4.0 (Jandel Scientific Corporation, USA). Regression lines were fitted through the plotted data and it was found that there was significant linear regression $(\mathrm{P}<0.05$ to $\mathrm{P}<0.001)$ are given in Table 1 . Such plots are shown in Figure 1. Hence, the growth was exponential over the $48 \mathrm{~h}$ incubation period in all the five rivers studied. The slope of the regression line gave specific growth rate $(k)$ of bacterioplankton.

(2) In routine determinations made at intervals over 24 months, two $5 \mathrm{ml}$ aliquots were taken only at 0 and $48 \mathrm{~h}$. In the preliminary determinations, SGR $\left(\mathrm{h}^{-1}\right)$ was obtained from linear regression of $\log _{\mathrm{e}}$ of the bacterial concentration against time where SGR equaled the regression coefficient. From direct counts of bacteria at $0 \mathrm{~h}$ and $48 \mathrm{~h}$. Exponential growth was assumed and the Specific Growth Rate $(k)$ of bacterioplankton was calculated using the following equation (Koch, 1981):

$$
\begin{aligned}
& \quad \log _{e} N_{t}=\log _{e} N_{0}+k t \\
& \therefore \quad \log _{e} N_{t}-\log _{e} N_{0}=k t \\
& \therefore k=\left(\log _{e} N_{t}-\log _{e} N_{0}\right)=t \\
& \therefore k=\log _{e}\left(N_{t} / N_{0}\right)=t
\end{aligned}
$$

Where, $N_{0}=$ is the concentration of bacteria at zero time $\left(\mathrm{ml}^{-1}\right)$

$N_{t}=$ is the concentration of bacteria at $48 \mathrm{~h}\left(\mathrm{ml}^{-1}\right)$

$\mathrm{t}=$ is the duration of incubation (h) and

$k=$ Specific Growth Rate of bacterioplankton $\left(\mathrm{h}^{-1}\right)$.

Both the methods gave similar $k$ values in that the second method was within the $95 \%$ confidence intervals around $k$ obtained by the first method. It was therefore decided to use the second method for routine determination of Specific Growth Rate $(k)$ since counts were needed only at $0 \mathrm{~h}$ and $48 \mathrm{~h}$. This was therefore, an economical and quick method. Hence, in routine measurements 5 $\mathrm{ml}$ aliquots were collected from each replicate flask only at the beginning of the incubation at $0 \mathrm{~h}\left(N_{0}\right)$ and at $48 \mathrm{~h}\left(N_{t}\right)$.

\section{Statistical Analysis}

Scaled (so that all values were $>1$ ) and then $\log _{10}$ transformed values of Specific Growth Rates $(k)$ were used for the one-sample Kolmogorov-Smirnov test, the Student-Neuman-Keuls test, one-way ANOVA and calculation of Pearson's correlation coefficients and stepwise multiple regression analysis. To scale raw $K$ values the lowest positive value was added to all values, the values were then multiplied by a constant to make them $>1$. All the negative $K$ values which were obtained from all the five water courses were considered as zero values, for these tests.

\section{RESULT AND DISCUSSION}

The results from routine determination of the specific growth rate $(k)$ of heterotrophic planktonic bacteria measured, for all the five rivers studied are summarized in Table 2 . The mean values with different superscripts are significantly different $(\mathrm{p}<0.05)$ as shown by one-way ANOVA post hoc non-parametric Student-Newman-Keuls test (SNK test) is also shown in this table. The interrelationship between the specific growth rate of bacterioplankton and other microbial variables were investigated by calculation of Pearson's Correlation Coefficients after $\log _{10}$ transformation of all five water courses are given in Table 3 . The mean value of specific growth rate (SGR) of heterotrophic bacteria was similar in the rivers Harangi (mean 0.0024, range -0.0016 $-0.011 \mathrm{~h}^{-1}$ ), Hemavathy (mean 0.0031, range $-0.0024-0.011 \mathrm{~h}^{-1}$ ), Lokapavani (mean 0.0030, range $-0.0019-0.009 \mathrm{~h}^{-1}$ ) and 
Cauvery (mean 0.0033, range $-0.004-0.0105 \mathrm{~h}^{-1}$ ). But it was more and was also significantly different in the river Lakshmanatheertha (mean 0.0042 , range $-0.0009-0.009 \mathrm{~h}^{-1}$ ) when compared to remaining four water courses studied. Further, there was a mean growth rate of $0.0024 \mathrm{~h}^{-1}$ which equal to 0.06 bacterium per day in river Harangi, $0.0031 \mathrm{~h}^{-1}$ which equal to 0.07 bacterium per day in river Hemavathy, $0.0030 \mathrm{~h}^{-1}$ which equal to 0.07 bacterium per day in river Lokapavani and $0.0033 \mathrm{~h}^{-1}$ which equal to 0.08 bacterium per day in river Cauvery. In contrast, in the river Lakshmanatheertha, the mean specific growth rate of heterotrophic bacteria was $0.0042 \mathrm{~h}^{-1}$ which was equal to 0.10 bacterium per day. This observation suggests that the river Lakshmanatheertha was more favorable environment for the growth of planktonic bacteria. The initial hypothesis was that the four upstream tributaries are similar to each other in having similar mean SGR of heterotrophic bacteria, but are markedly different from that of the main river Cauvery was rejected, because the mean SGR of heterotrophic bacteria was comparatively more and significantly different in the river Lakshmanatheertha only. Low level of water, intense human activities, discharge of sewage, agricultural wastes and eutrophic nature was noticed in the river Lakshmanatheertha, all of which might have enriches the nutrient level, may be the reason for increased bacterial SGR in this river. Similarly, the nutrient rich in the water markedly stimulated the bulk of bacterioplankton production, as well as changes in the growth rate of bacterioplankton as represented by Simek, et al., 2005; Jezbera, et al., 2005. Recently, several investigators have demonstrated that, bacterial growth in aquatic ecosystems can be limited by the availability of allochthonous DOC (del Giorgio and peters, 1994; Church, 2008). Further, in the present investigation, comparatively more negative SGR of heterotrophic bacteria was noticed in the river Lakshmanatheertha. For example, out of 50 determination 15 in river Lakshmanatheertha, 2 in river Harangi, 1 in river Hemavathy, 3 in river Lokapavani, and 2 in river Cauvery (Figure 2). The negative specific growth rates were due to decrease in the observed bacterial cell counts after $48 \mathrm{~h}$ incubation. Coveney and Wetzel (1992) have reported the negative specific growth rates in Oligotrophic lake water samples, ranged from -0.1 to greater than 1.5 per day. Yamakanamardi and Goulder (1999) reported negative growth rate in the Holderness Drain for eight occasions out of 28 determinations. Chrzanowski and Grover (2001) have also recorded negative growth occasionally in control bottles of their experiments. Similarly, negative growth rates were recorded in the river Cauvery and its downstream tributaries (Harsha et al 2009), suggesting higher grazing-induced mortality (Jezbera, et al., 2005; Simek, et al., 2005; Jürgens and Massana, 2008; Vaqué et al., 2014). Further, some of the bacteria may have become attached to the walls of the experimental flasks; hence these bacteria would not be counted, thus rendering the $48 \mathrm{~h}$ bacterial counts less than $0 \mathrm{~h}$ bacterial counts (Kristiansen, et al., 1992). The calculations of Pearson's correlation coefficients $(\mathrm{p}<0.01)$ between SGR of heterotrophic bacteria and other microbial variables (Tables 3) revealed that the SGR $(k)$ of heterotrophic bacteria showed few correlations with the other microbial variables. In the river Lakshmanatheertha the SGR of heterotrophic bacteria showed only negative correlations with abundance of directly counted free living bacteria, particle bound bacteria, total bacteria and CFU's. In the river Harangi, the SGR of bacteria was negatively correlated only with the abundance of directly counted particle bound bacteria. In river Hemavathy, the SGR of heterotrophic bacteria was positively correlated with mean length of free living and particle bound bacteria. In rivers Lokapavani and Cauvery the SGR of planktonic bacteria was not correlated with any of the microbial variables. Generally, the negative correlation between SGR and bacterial abundance in the rivers Lakshmanatheertha and Harangi implies that, lesser the bacterial abundance higher will be the SGR of planktonic bacteria (Kirchman, 2008). For instance; the carbon and energy source or essential nutrients becomes completely used up by the heterotrophic bacteria during their growth, when a carbon source is used up it doesn't necessary mean that all growth stops. This is because, dying bacterial cells can lyse and provide source of nutrients for growing bacteria. Hence, the negative relation between the abundance and growth rate may suggest that endogenous metabolism (Maier, 2000). Relatively low bacterial abundance could be ascribed to the differential interactions among bacterial growth rate, physical circulation, substrate supply, bacteriophages, bacterivory and other predation in regulating bacterial abundance (Ducklow and Shiah., 1993; Hahn, et al., 1999; Church, 2008; Vaqué et al., 2014). Berman et al., (1994) reported that even though samples were prefiltered gently through $1.0 \mu \mathrm{m}$ and $0.8 \mu \mathrm{m}$ polycarbonate membranes, some flagellates or other bacteriovorous protozoa, as well as bacteriophages, may have been present and could have 
ISSN 2250-3153

interfered with bacterial growth rate (Chrzanowski and Grover, 2001; Carlson and Caron, 2001). The planktonic bacteria were also eliminated by viruses which induced bacterial mortality (Vaqué et al., 2014). Whereas, in the river Hemavathy, the bacterial growth rate was positively correlated with the mean lengths of bacteria. Similar positive correlation was also noticed in the Holderness Drain of North-East England (Yamakanamardi, 1995), and in the river Cauvery and its four downstream tributaries of south Karnataka, India (Harsha et al, 2009).

Table. 1. Table showing Specific Growth Rate (SGR) of aquatic heterotrophic bacteria $\left(k \mathbf{h}^{-1}\right)$ values determined by linear regression.

\begin{tabular}{|l|c|c|c|}
\hline \multicolumn{1}{|c|}{ Sampling Sites } & Mean (Range) & \multicolumn{2}{c|}{ F value } \\
\hline River Lakshmanatheertha & $1.380(1.10-1.83)$ & 12.19 & $\mathrm{P}<0.05$ \\
\hline River Harangi & $1.124(0.89-1.34)$ & 6.253 & $\mathrm{P}<0.05$ \\
\hline River Hemavathy & $1.142(0.97-1.29)$ & 7.525 & $\mathrm{P}<0.01$ \\
\hline River Lokapavani & $1.528(1.30-1.82)$ & 9.192 & $\mathrm{P}<0.05$ \\
\hline River Cauvery & $1.274(1.09-1.45)$ & 5.126 & $\mathrm{P}<0.01$ \\
\hline
\end{tabular}

The $\log _{\mathrm{e}}$ transformed direct counts of bacteria at $0,12,24,36$, and $48 \mathrm{~h}$, of both the replicates, were used for linear regression analysis, hence $n=10$. Overall $F$ and $P$ values for each rivers are given. The regression coefficients of SGR of all the rivers were significantly different. 
Table 2. Summary of Specific Growth Rate of heterotrophic bacterioplankton in the surface waters from Rivers Lakshmanatheertha, Harangi, Hemavathy, Lokapavani and Cauvery.

\begin{tabular}{|c|c|c|c|c|c|c|c|c|c|c|}
\hline \multirow{2}{*}{$\begin{array}{l}\text { Bacterial } \\
\text { variable }\end{array}$} & \multicolumn{2}{|c|}{ River Lakshmanatheertha } & \multicolumn{2}{|c|}{ River Harangi } & \multicolumn{2}{|c|}{ River Hemavathy } & \multicolumn{2}{|c|}{ River Lokapavani } & \multicolumn{2}{|c|}{ River Cauvery } \\
\hline & Mean (Range) & CV\% & Mean (Range) & $\mathrm{CV} \%$ & Mean (Range) & $\mathrm{CV} \%$ & Mean (Range) & $\mathrm{CV} \%$ & Mean (Range) & $\mathrm{CV} \%$ \\
\hline $\operatorname{SGR}\left(\mathrm{Kh}^{-1}\right)$ & $\begin{array}{c}\mathbf{0 . 0 0 4 2}^{\mathbf{b}} \\
(-0.0009-0.009)\end{array}$ & 105 & $\begin{array}{c}\mathbf{0 . 0 0 2 4}^{\mathbf{a}} \\
(-0.0016-0.011)\end{array}$ & 83 & $\begin{array}{c}\mathbf{0 . 0 0 3 1}^{\mathbf{a}} \\
(-0.0024-0.011)\end{array}$ & 71 & $\begin{array}{c}\mathbf{0 . 0 0 3 0}^{\mathbf{a}} \\
(-0.0019-0.009)\end{array}$ & 73 & $\begin{array}{c}\mathbf{0 . 0 0 3 3}^{\mathbf{a}} \\
(-0.004-0.0105)\end{array}$ & 79 \\
\hline
\end{tabular}

Mean Values with different superscripts are significantly different $\left(\mathrm{P}<0.05\right.$, Student-Newman-Keuls test, after $\log _{10}$ transformation $)$. CV= Coefficient of Variation, $\mathrm{SGR}=\mathrm{Specific}$ Growth Rate.

Table 3. Relationships between Specific Growth Rate $(k)$ of heterotrophic bacteria and other microbial variables, in river Cauvery and its four upstream tributaries.

\begin{tabular}{|c|c|c|c|c|c|c|c|c|c|c|c|}
\hline \multirow[b]{2}{*}{ Sampling Sites } & \multicolumn{11}{|c|}{ Microbial variables } \\
\hline & DC-FLB & DC-PBB & DC-TB & CFUs & $\%$ CCFUs & $\begin{array}{l}\text { CFUs as } \% \\
\text { of AODCs }\end{array}$ & ML-FLB & ML-PBB & Phytoplankton & Zooplankton & Total plankton \\
\hline $\begin{array}{l}\text { River } \\
\text { Lakshmanatheertha }\end{array}$ & $-0.29 *$ & $-0.28 *$ & $-0.29 *$ & $-0.41 * *$ & NS & NS & NS & NS & NS & NS & NS \\
\hline River Harangi & NS & $-0.35 *$ & NS & NS & NS & NS & NS & NS & NS & NS & NS \\
\hline River Hemavathy & NS & NS & NS & NS & NS & NS & $0.31 *$ & $0.29 *$ & NS & NS & NS \\
\hline River Lokapavani & NS & NS & NS & NS & NS & NS & NS & NS & NS & NS & NS \\
\hline River Cauvery & NS & NS & NS & NS & NS & NS & NS & NS & NS & NS & NS \\
\hline
\end{tabular}

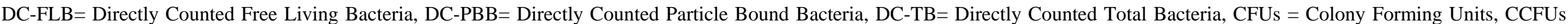

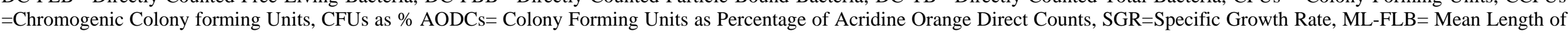
Free Living Bacteria, ML-PBB = Mean Length of Particle Bound Bacteria. 


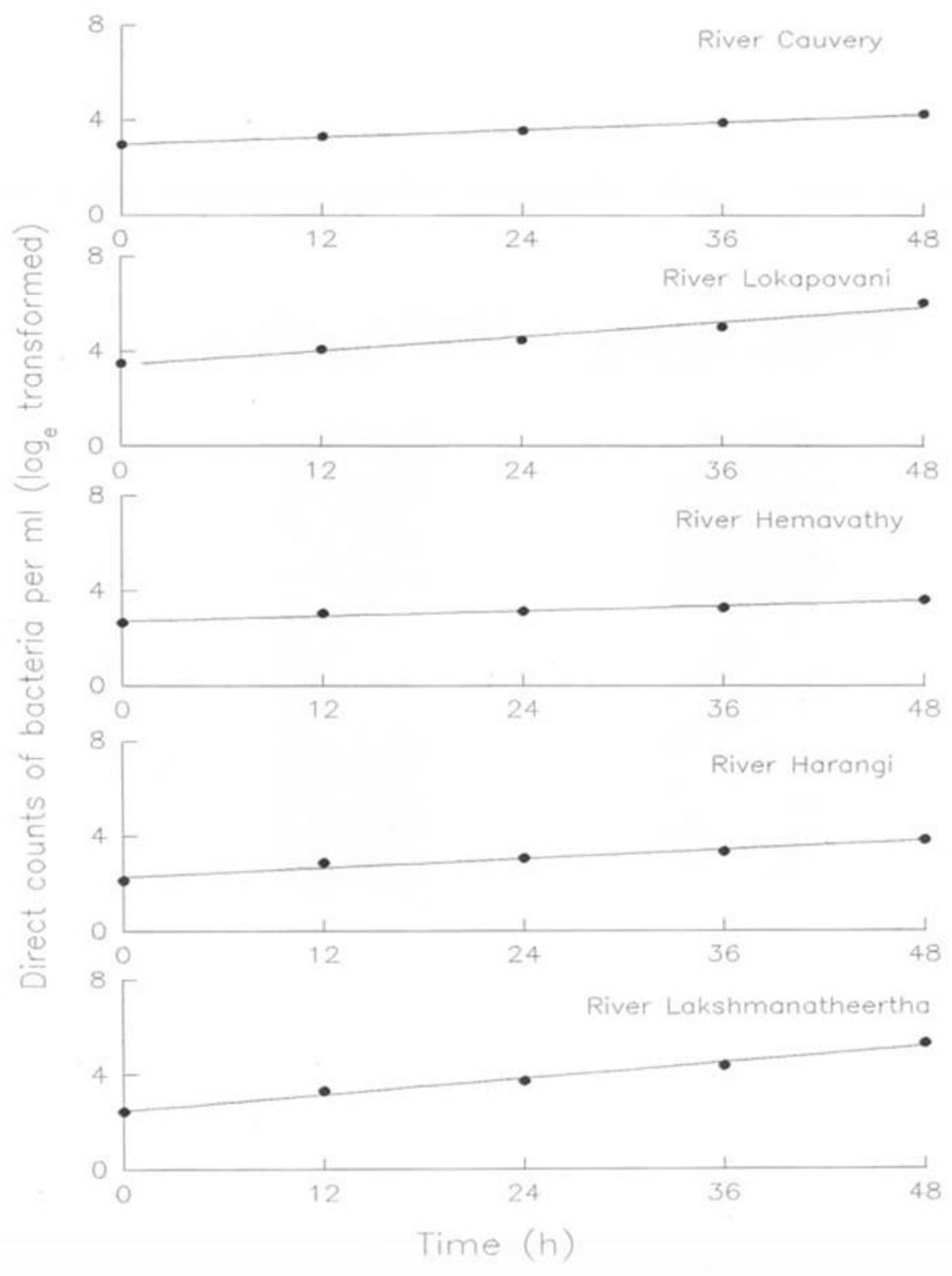

Figure 1. Graph showing $\log _{\mathrm{e}}$ transformed direct count of Heterotrophic Bacteria per ml plotted against time in GF/A filtered samples from respective rivers. There were two replicate incubation of each water samples. 


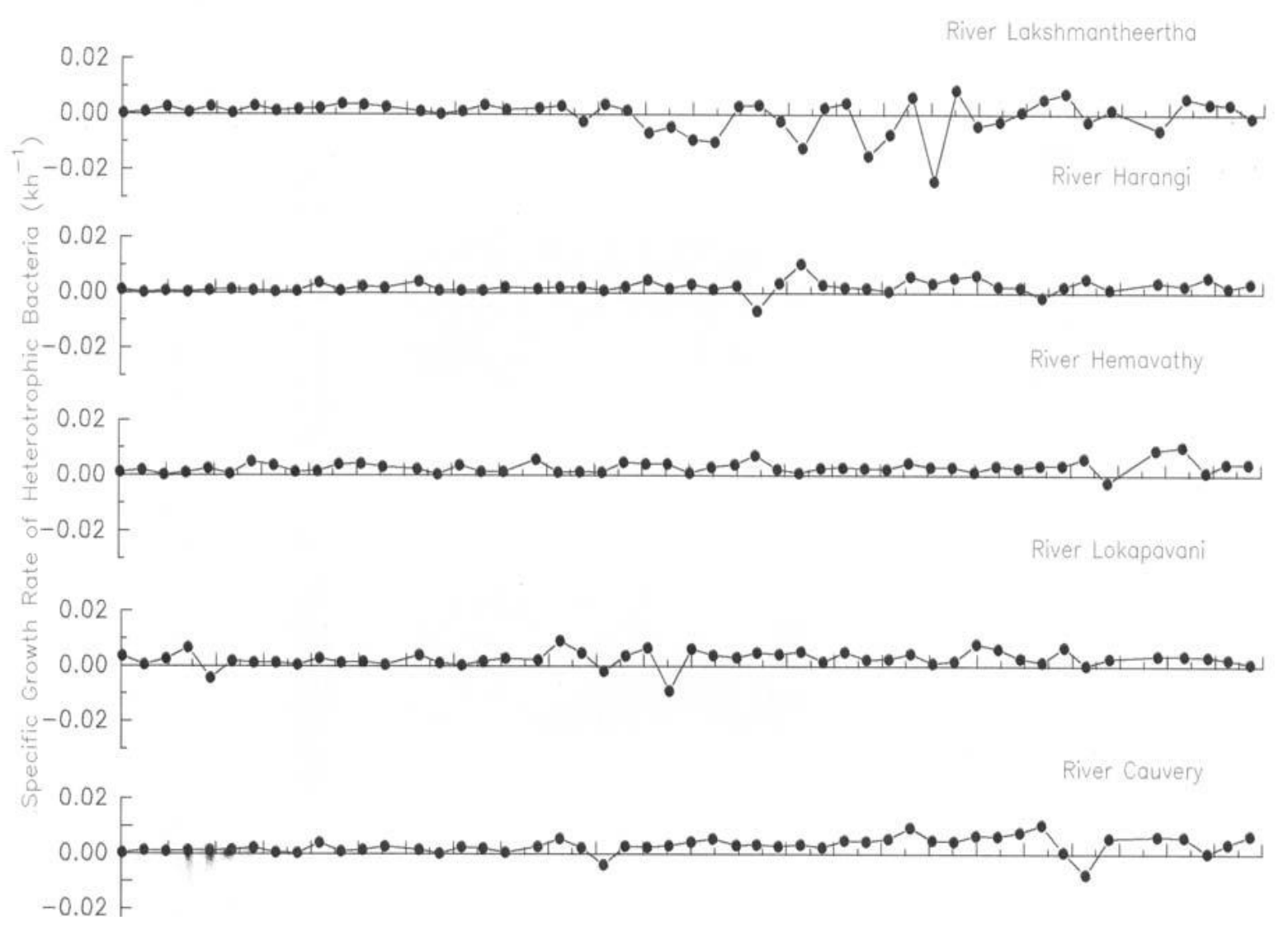

Figure 2. Temporal variation in the Specific Growth Rate of Heterotrophic Bacteria (k) showing negative growth rate in the surface water of river Cauvery and its four upstream tributaries.

\section{CONCLUSION}

In conclusion, more and significantly different SGR of bacterioplankton was noticed in the river Lakshmanatheertha. Further, the result described here revealed that, there was a mean growth rate of $0.0024 \mathrm{~h}^{-1}$ which equal to 0.06 bacterium per day in river Harangi, $0.0031 \mathrm{~h}^{-1}$ which equal to 0.07 bacterium per day in river Hemavathy, $0.0030 \mathrm{~h}^{-1}$ which equal to 0.07 bacterium per day in river Lokapavani and $0.0033 \mathrm{~h}^{-1}$ which equal to 0.08 bacterium per day in river Cauvery. In contrast, in the river Lakshmanatheertha, the mean specific growth rate of heterotrophic bacteria was $0.0042 \mathrm{~h}^{-1}$ which equal to 0.10 bacterium per day. This observation suggests that the river Lakshmanatheertha was more favorable ecosystem for the bacterial growth than the other four watercourses studied. This was due to maximum anthropogenic activities, increased nutrient level, pollution, sewage and other effluent contamination. Several studies supportively evidenced that, the nutrient rich in the water markedly stimulated the bulk of bacterioplankton production, as well as changes in the growth rate of planktonic bacteria. Further, only few negative correlations were noticed between SGR and other microbial variables in the rivers Lakshmanatheertha and Harangi implies that, lesser the bacterial abundance higher will be the SGR of planktonic bacteria. While in river Hemavathy the SGR positive correlation with the mean length of bacteria. Similar positive correlation was also noticed in the Holderness Drain of North-East England (Yamakanamardi, 1995), and in the river Cauvery and its four downstream tributaries of south Karnataka, India (Harsha et al, 2009). Further, in the present investigation, comparatively more negative SGR of heterotrophic bacteria was noticed in the river Lakshmanatheertha. For example, out of 50 determination 15 in river Lakshmanatheertha, 2 in river Harangi, 1 in river Hemavathy, 3 in river Lokapavani, and 2 in river Cauvery. The negative specific growth rates were a result of decrease in the observed bacterial cell counts after $48 \mathrm{~h}$ incubation. Relatively low bacterial abundance could be ascribed to the differential 
interactions among bacterial growth rate, physical circulation, substrate supply, bacteriophages, bacterivory and other predation in regulating bacterial abundance which in turn interfere with the growth rate of planktonic bacteria.

\section{REFERENCES}

Alonso-Sáez, L., Vazquez Dominguez, E., Cardelús, C., Pinhassi, J., Sala, M. M., Lekunberri, I. (2008). Factors controlling the year-round variability in carbon flux through bacteria in a coastal marine system. Ecosystems 11, 397-409.

Azam, F., Fenchel, T., Field, J. G., Gray, J.S., Meyer-Reil, L.A., and Thingstad, F. (1983). The ecological role of water-column microbes in the sea. Mar Ecol Prog Ser, 10: 257 - 263.

Berman, T., Hoppe, H.G., and Gocke, K. (1994). Response of aquatic bacterial population to substrate enrichment. Mar. Ecol. Prog. Ser., 104, 173 - 184.

Carlsson, P., and Caron, D.A (2001). Seasonal variation of phosphorus limitation of bacterial growth in a small lake. Limnol. Oceanogr, 46(1): $108-120$.

Caron, D. A., (1991). Evolving role of protozoa in aquatic nutrient cycles, 387-415. In P.C. Reid., C.M. Turley, and P.H. Burkill (eds), protozoa and their role in marine processes. Springer-Verlag.

Chrzanowski, T.H., and Grover, J. P. (2001). Effects of mineral nutrients on the growth of bacterio - and phytoplankton in two southern reservoirs. Limnol. Oceanogr, 46(6): 1319 -1330.

Church, M. J. (2008). "Resource control of bacterial dynamics in the Sea," in Microbial Ecology of the Oceans, ed. D. L. Kirchman (Honolulu, HI: University of Hawaii at Manoa), 335-382.

Coveney, M. F., and Wetzel, R. G. (1992). Effects of nutrients on specific growth rate of bacterioplankton in oligotrophic lake water cultures. Appl. Environ. Microbiol, 58: 150 -156.

del Giorgio, P. A., and Peters, R. H. (1994). Patterns in planktonic P:R ratios in lakes: influence of lake trophy and dissolved organic carbon. Limnol. Oceanogr., 39: 772 - 787.

Ducklow, H. W., and Hill, S. M. (1985). The growth of heterotrophic bacteria in the surface waters of warm core rings. Limnol Oceanogr, 30(2): 239 - 259.

Ducklow, H. W., and Shiah, F. (1993). Bacterial production in estuaries. In T.E. Ford (ed), Aquatic microbiology: An ecological approach. Blackwell. 261 - 288.

Findlay, S., Pace, M. L., Fischer, D. T. 1998. Response of heterotrophic bacteria to the Zebra Mussel Invasion of the Tidal Fresh water Hudson River. Microb Ecol, 36: 131-140.

Foreman, C. M. Franchini, P., and Sinsabaugh, R. L. (1998). The trophic dynamics of riverine bacterioplankton: Relationships among substrate availability, ectoenzyme kinetics and growth. Limnol. Oceanogr., 43(6): 1344 - 1352.

Fry, J. C. (1990). Direct methods and biomass estimation. Methods in microbiology, 22: 41 - 85.

Giorgio, P. A. D., and Cole, J. J. (1998). Bacterial growth efficiency in natural aquatic systems. Annu. Rev. Ecol.Syst, 29: 503 541 .

Hahn, M. W., and Höfle, M. G. (1999). Flagellate predation on a bacterial model community: Interplay of size-selective grazing, specific bacterial cell size, and bacterial community composition. Appl Environ Microbiol, 65: 4863 - 4872.

Harsha T.S, Sadanand M Yamakanamardi, Mahadevaswamy. M; Temporal variation in the specific growth rate of bacterioplankton in the river Cauvery and its four down stream tributaries in Karnataka State, India. Environ Monit Assess (2009) 154: 169-185

Henssen, D. D., and Tranvik, L. J. (1998). Aquatic humic substances: Ecology and biochemistry, Springer Verlag, Berlin.

Huete-Stauffer, T. M., Arandia-Gorostidi, N., Díaz-Pérez, L., and Morán, X. A. G. (2015). Temperature dependences of growth rates and carrying capacities of marine bacteria depart from metabolic theoretical predictions. FEMS Microbiol. Ecol. 91, $1-10$. 
Iriberri, J., Unanue, M., Ayo, B., Barcina, I., and Egea, L. (1990). Bacterial production and growth rate estimation from [ ${ }^{3}$ H] thymidine incorporation for attached and free-living bacteria in aquatic systems. Appl. Environ. Microbiol, 56: 483 - 487.

Jezbera, J., Hornak, K., and Simek, K. (2005). Food selection by bacteriovorous protests; insight from the analysis of the food vacuole content by means of fluorescence in situ hybridization. FEMS Microbiol Ecol, 52: 351 - 363.

Jugnia, L. B., Tadonléké, R. D., Simi-Ngando, T., and Devaux, J. (2000). The microbial food web in the recently flooded sep reservoir: diel fluctuations in bacterial biomass and metabolic activity in relation to phytoplankton and flagellate grazers. Microb Ecol, 40: 317 - 329.

Jürgens, K., and Massana, R. (2008). "Protistan grazing on marine bacterioplankton," in Microbial Ecology of the Oceans, 2nd Edn, ed. D. L. Kirchman (Hoboken, NJ: Wiley), 383-441.

Kirchman, D. L. (2008). New light on an important microbe in the ocean. Proc. Natl. Acad. Sci. U.S.A. 105, 8487-8488. doi: 10.1073/pnas.0804196105

Kirchman, D. L., Morán, X. A. G., and Ducklow, H. (2009). Microbial growth in the polar oceans - role of temperature and potential impact of climate change. Nat. Rev. Microbiol. 7, 451-459. doi: 10.1038/nrmicro2115

Kirchman, D. L. (2015). Growth rates of microbes in the Oceans. Ann. Rev. Mar. Sci. 8, 285-309.

Koch, A. L. 1981. Growth measurement In: Manual of methods for general bacteriology (Ed.) Gerhardt, P. American Society for Microbiology, USA.

Kristiansen, K., Nielsen, H., Rieman, B., and Fuhrman, J. A. (1992). Growth efficiencies of freshwater bacterioplankton. Microb. Ecol, 24: 145 -160.

Kritzberg, E. S., Cole, J. J., Pace, M. L., Graneli, W., Bade, D. L. (2004). Autochthonous vs allochthonous Carbon sources of bacteria, results from whole lake ${ }^{13} \mathrm{C}$ addition experiments. Limnol Oceanogr, 49: 588 - 596.

Lambert, D. L., Taylor, P. N., and Goulder, R. (1993). Between site comparisons of fresh water Bacterioplankton by DNA hybridization. Microb. Ecol, 26: 189 - 200.

Li, K. W. (1984). Microbial uptake of radiolabelled substrates: Estimates of growth rates from time course measurements. Appl. Environ. Microbiol, 47: 184 - 192.

Lønborg, C., Martínez-García, S., Teira, E., and Álvarez-Salgado, X. A. (2011). Bacterial carbon demand and growth efficiency in a coastal upwelling system. Aquat. Microb. Ecol. 63, 183-191.

Maier, R. M. (2000). Bacterial Growth. In: Environmental Microbiology (ed); Maier, R. M. Pepper, I. L., and Gerba, C. P. Academic Press, California, USA. pp 43 - 59.

Pace, M.L., Mc Manus, G. B., Findlay, S. E. G. (1990). Planktonic community structure determines the fate of bacterial production in a temperate lake. Limnol Oceanogr, 35: 95 - 108.

Pomeroy, T. L., Sheldon, E., Sheldon, W. M., and Peters, F. (1995). Limits to growth and respiration of bacterioplankton in the Gulf of Mexico. Mar.Prog.Ser. 117: 259 -

Proctor, L. M., and Fuhrman. J. A. 1992. Mortality of marine bacteria in response to enrichments of the virus size fraction from seawater. Mar. Ecol. Prog. Ser. 87: 283

Rivkin, R. B., and Anderson, M. R. (1997). Inorganic nutrient limitation of oceanic bacterioplankton. Limnol. Ocenogr, 42: 730 740 .

Sanders, R. W., Caron, D. A., and Berninger, U. G. (1992). Relationship between bacteria and heterotrophic nanoplankton in marine and fresh waters: an inter-ecosystem comparison. Mar Ecol Prog Ser, 86: 1 - 14. 
International Journal of Scientific and Research Publications, Volume 10, Issue 7, July 2020

ISSN 2250-3153

Šimek, K., Hornak, K., Jezbera, J., Jezbera, J., Nedoma, J., Vrba,J., Straskrabova, V., Macek, M., Dolan, R.J, and Martin W. Hahn, (2006). Maximum growth rates and possible life strategies of different bacterioplankton groups in relation to phosphorous availability in a fresh water reservoir. Environmental Microbiology, 1 - 12.

Šimek, K., Hornak, K., Jezbera, J., Masin, M., Nedoma, J., Gasol, J. M., and Schauer, M. (2005). Influence of top-down and bottom-up manipulations on the R-BT065 sub cluster of $\beta$-proteobacteria, an abundant group in bacterioplankton of fresh water reservoir. Appl Environ Microbiol, 71: 2381 - 2390.

Sinsabaugh, R. L., Findlay, S., Franchini, P., and Fischer, D. (1997). Enzymatic analysis of riverine bacterioplankton production. Limnol. Oceanogr. 42: 29 - 38.

Tranvik, L. (1998). Degradation of dissolved organic matter in humic waters by bacteria. Ecology and biogeochemistry. SringerVerlag, Berlin, 259 - 284.

Vaqué, D., Alonso-Sáez, L., Arístegui, J., Agustí, S., Duarte, C. M., Montserrat Sala, M., et al. (2014). Bacterial production and losses to predators along an open ocean productivity gradient in the Subtropical North East Atlantic Ocean. J. Plankton Res. 36, 198-213.

Yamakanamardi, S. M. (1995). Microbial ecology of three contrasting lowland water courses in Northeast England. Ph. D, Thesis. The University of Hull, England, U K.

Yamakanamardi, S. M., and Goulder, R. (1999). Specific growth rate of bacterioplankton, determined at constant temperature, as an indicator of deterioration in water quality. Environ Toxicol., 14: 309 - 312. 